\title{
Glutaraldehyde Enhancement by D-limonene for Mitigating Biocorrosion of Carbon Steel by An Oilfield Biofilm Consortium
}

\section{Pruch Kijkla}

Ohio University

\section{Di Wang}

Ohio University

Magdy E. Mohamed

Saudi Aramco Schools: Saudi Aramco Expatriate Schools

Mazen A. Saleh

Saudi Aramco Schools: Saudi Aramco Expatriate Schools

\section{Sith Kumseranee}

PTT Exploration and Production

\section{Suchada Punpruk}

PTT Exploration and Production

\section{Tingyue Gu ( $\nabla$ gu@ohio.edu )}

Ohio University https://orcid.org/0000-0002-4208-210X

\section{Research Article}

Keywords: carbon steel, microbiologically influenced corrosion, biofilm consortium, biocide

Posted Date: April 6th, 2021

DOl: https://doi.org/10.21203/rs.3.rs-286491/v1

License: (9) This work is licensed under a Creative Commons Attribution 4.0 International License. Read Full License 


\section{Abstract}

Microbiologically influenced corrosion (MIC) is one of the corrosion threats in the oil and gas industry. It is caused by environmental biofilms. Glutaraldehyde is a popular green biocide for mitigating biofilms and MIC. This work investigated the enhancement of glutaraldehyde efficacy by food-grade green chemical D-limonene in the biofilm prevention and MIC mitigation using an oilfield biofilm consortium. After 7-d incubation at $37^{\circ} \mathrm{C}$ with enriched artificial seawater (EASW) in $125 \mathrm{~mL}$ anaerobic vials, the 100 ppm glutaraldehyde +200 ppm D-limonene combination treatment reduced the sessile cell counts on C1018 carbon steel coupons by 2.1 - log, 1.7 - log, and 2.3 - log for SRB (sulfate reducing bacteria), APB (acid producing bacteria), and GHB (general heterotrophic bacteria), respectively in comparison with the untreated control. The treatment achieved $68 \%$ weight loss reduction and $78 \%$ pit depth reduction. The 100 ppm glutaraldehyde +200 ppm D-limonene combination treatment was found more effective in biofilm prevention and MIC mitigation than glutaraldehyde and D-limonene used individually. Electrochemical tests corroborated weight loss and pit depth data trends.

\section{Introduction}

Biocorrosion, more commonly known as microbiologically influenced corrosion (MIC) in the literature, is one of the root causes of equipment failures, especially for pipelines in the oil and gas industry. MIC accounts for $20 \%$ of total corrosion losses (Dall'Agnol and Moura 2014), which amounts to approximately 30-50 billion US dollars per year worldwide (Javaherdashti 1999). Microbial biofilms cause MIC. Biocides are routinely used to treat biofilms to mitigate the risk of MIC failures. The desired biocide should have broad-spectrum efficacy and safety to the environment and field operators.

SRB are microbes that thrive in an anaerobic environment with sulfate. They can survive exposure to oxygen but without growth (Bade et al. 2000). SRB uses the dissimilatory sulfate reduction process to couple the oxidation of an energy molecule such as organic carbon or dissolved hydrogen gas. When there is a local shortage in organic carbon, or the sessile cells are in the resting (non-growth) state, SRB can switch to elemental iron as the electron donor in energy production. This mechanism is the BCSR theory (biocathode theory) (Gu et al. 2018). Lactate oxidation reaction provides an energy source, as shown in Reaction (1). SRB produces $\mathrm{HS}^{-}$from sulfate respiration in reaction (2). $\mathrm{HS}^{-}$then combines with a proton to become $\mathrm{H}_{2} \mathrm{~S}$ or release a proton to become sulfide, as shown in Reactions (4) and (5), respectively. $\mathrm{HS}^{-}$can also react with $\mathrm{Fe}^{2+}$ in Reaction (3) to form FeS as presented in Reaction (6), which appears as a black color product when it is precipitated out in the culture medium beyond saturation (Jia et al. 2019).

$2 \mathrm{CH}_{3} \mathrm{CHOOHOCOO}+2 \mathrm{H}_{2} \mathrm{O} \rightarrow 2 \mathrm{CH}_{3} \mathrm{COO}^{-}+2 \mathrm{CO}_{2}+8 \mathrm{H}^{+}+8 \mathrm{e}^{-}(1)$

Reduction reaction (cathodic) $\mathrm{SO}_{4}{ }^{2-}+9 \mathrm{H}^{+}+8 \mathrm{e}^{-} \rightarrow \mathrm{HS}^{-}+4 \mathrm{H}_{2} \mathrm{O}(2)$

Iron oxidation reaction (anodic) $4 \mathrm{Fe} \rightarrow 4 \mathrm{Fe}^{2+}+8 \mathrm{e}^{-}$(3) 
$\mathrm{HS}^{-}+\mathrm{H}^{+} \leftrightharpoons \mathrm{H}_{2} \mathrm{~S}(4)$

$\mathrm{HS}^{-} \leftrightharpoons \mathrm{H}^{+}+\mathrm{S}^{2-}(5)$

$\mathrm{Fe}^{2+}+\mathrm{HS}^{-} \leftrightharpoons \mathrm{FeS}+\mathrm{H}^{+}(6)$

The sulfate reduction reaction happens in the cytoplasm of SRB with enzyme catalysis, but the electrons from $\mathrm{Fe}^{0}$ (insoluble) oxidation are released extracellularly. This means that extracellular electrons need to be transported to the cytoplasm for sulfate reduction. This electron transport process is known as the extracellular electron transfer (EET) process (Gu et al. 2018). Mesophilic SRB produces the maximum corrosion rate at a mild temperature, such as $37^{\circ} \mathrm{C}$ (Rasol et al. 2014). Thermophilic SRB and SRA (sulfate reducing archaea) prefer much higher temperatures, such as reservoir temperatures of 70 or $80^{\circ} \mathrm{C}$.

Glutaraldehyde $\left(\mathrm{C}_{5} \mathrm{H}_{8} \mathrm{O}_{2}\right)$ is an antimicrobial substance that is commonly used to disinfect medical devices. In the oil and gas industry, it is used as a biodegradable biocide to treat biofilms for the mitigation of MIC (Keasler et al. 2017). Glutaraldehyde is water-soluble. Its efficacy drops for temperatures above $50^{\circ} \mathrm{C}$. For environmental and operational concerns, it is desirable to reduce its dosage with a biocide enhancer. Wen et al. (Wen et al. 2009) demonstrated that ethylene amine disuccinate (EDDS), which is a green chemical, enhanced glutaraldehyde mitigation of Desulfovibiro vulgaris (a common SRB strain) biofilm on carbon steel. A high concentration of EDDS (2,000 ppm by mass) is needed because some of it is consumed by ions that it chelates in the liquid.

D-amino acids have been found to enhance THPS (tetrakis hydroxymethyl-phosphonium sulfate) against D. vulgaris, and also a recalcitrant corrosive oilfield biofilm caodenamed Consortium II (Jia et al. 2017). More recently, Jia et al. reported that a 14 - mer peptide with its 12 - mer core sequence derived from a sea anemone's Equinatoxin II at 18 ppb (w/w) enhanced Consortium II considerably. Because glutaraldehyde is a potent crosslinker of peptides (Migneault et al. 2004), it is not compatible with Damino acids and Peptide A. Thus, it is desirable to find other green chemicals that can enhance glutaraldehyde, which is the most popular green biocides together with THPS in the oil and gas industry.

D-limonene $\left(\mathrm{C}_{10} \mathrm{H}_{16}\right)$ is a biodegradable antimicrobial agent found in some "green" household cleaners (Van vuuren and Viljoen 2007; Settanni et al. 2012; Chikhoune et al. 2013). It is a common terpene that is extracted from oils of citrus fruits such as orange, lemon, and lime. It is considered safe for human use with slight irritation when in direct contact with the skin (Kim et al. 2013). Even though it is widely applied in the food industry as a flavoring agent and it is sold as a nutritional supplement (Dabbah et al. 1970), its application in biofilm treatment and MIC mitigation needs to be investigated since there is a lack of literature data.

This project compared glutaraldehyde efficacy and D-limonene efficacy and the efficacy of combining the two biocides in mitigation Consortium II and its MIC against C1018 carbon steel. Consortium II was 
grown on carbon steel coupons in EASW. Weight loss, sessile cell count, and electrochemical tests were used to assess biocide efficacy.

\section{Materials And Methods}

\section{Metal coupons and microbes}

The test coupon was cut from C1018 carbon steel. Its elemental composition is listed in Table 1. Coupons were protected with inert Teflon paint except for the top $1 \mathrm{~cm}^{2}$ square test area. Prior to incubation, coupons were sequentially abraded up to 600 grit, degreased with pure isopropanol, and air dried under ultraviolet light for at least $0.3 \mathrm{~h}$.

Table 1

Composition of C1018 carbon steel.

\begin{tabular}{|llllllllll|}
\hline Element & $\mathbf{C}$ & $\mathbf{M n}$ & $\mathbf{P}$ & $\mathbf{C r}$ & $\mathbf{S}$ & $\mathrm{Mo}$ & $\mathrm{Si}$ & $\mathrm{Ni}$ & $\mathrm{Fe}$ \\
\hline Amount (wt\%) & 0.200 & 0.900 & 0.017 & 0.061 & 0.012 & 0.018 & 0.044 & 0.044 & balance \\
\hline
\end{tabular}

Consortium II (Jia et al. 2017), a corrosive oilfield biofilm consortium, was used in all the tests in this work. It was grown in enriched artificial seawater (EASW) with composition listed in Table 2. The culture medium was sterilized and then deoxygenated using $\mathrm{N}_{2}$. L-cysteine (at $100 \mathrm{ppm}$ ) was added as a scavenger of $\mathrm{O}_{2}$. The culture medium's initial $\mathrm{pH}$ was adjusted to 7.0 before inoculation in a $\mathrm{N}_{2}$-filled glovebox. Each $125 \mathrm{~mL}$ vial was filled with $100 \mathrm{~mL}$ of EASW and 3 coupons. The inoculum was $1 \mathrm{~mL}$ 3-d old seed culture. 
Table 2

Composition of enriched artificial seawater.

\begin{tabular}{|c|c|}
\hline Chemical & Amount (g) \\
\hline $\mathrm{Na}_{2} \mathrm{SO}_{4}$ & 0.200 \\
\hline $\mathrm{NaCl}$ & 23.476 \\
\hline $\mathrm{NaHCO}_{3}$ & 0.192 \\
\hline $\mathrm{KBr}$ & 0.096 \\
\hline $\mathrm{KCl}$ & 0.664 \\
\hline $\mathrm{H}_{3} \mathrm{BO}_{3}$ & 0.026 \\
\hline $\mathrm{SrCl}_{2} \cdot 6 \mathrm{H}_{2} \mathrm{O}$ & 0.040 \\
\hline $\mathrm{MgCl}_{2} \cdot 6 \mathrm{H}_{2} \mathrm{O}$ & 10.610 \\
\hline $\mathrm{CaCl}_{2} \cdot 2 \mathrm{H}_{2} \mathrm{O}$ & 1.469 \\
\hline Yeast extract & 1 \\
\hline Tri-sodium citrate & 0.5 \\
\hline Sodium lactate & 3.5 \\
\hline $\mathrm{CaSO}_{4} \cdot 0.5 \mathrm{H}_{2} \mathrm{O}$ & 0.1 \\
\hline $\mathrm{NH}_{4} \mathrm{Cl}$ & 0.1 \\
\hline $\mathrm{MgSO}_{4} \cdot 7 \mathrm{H}_{2} \mathrm{O}$ & 0.71 \\
\hline $\mathrm{Fe}\left(\mathrm{NH}_{4}\right)_{2}\left(\mathrm{SO}_{4}\right)_{2} \cdot 6 \mathrm{H}_{2} \mathrm{O}$ & 1.38 \\
\hline Di water & $1 \mathrm{~L}$ \\
\hline
\end{tabular}

Sessile cell counting

When the $7-d$ incubation at $37^{\circ} \mathrm{C}$ ended, the coupons were retrieved. The sessile cells on each coupon were removed, suspended in a buffer and then counted using the most probable number (MPN) method. The MPN liquid culture media were modified Postgate's B (MPB) for SRB and standard bacterial nutrient broth for GHB. For APB, phenol red dextrose medium was used. All the MPN media were purchased from Biotechnology Solutions (Houston, TX). The MPN test tubes $\left(10^{7}\right.$ dilutions) were incubated at $37^{\circ} \mathrm{C}$ for 7 $-d$. 
After sessile cell counting, the coupons were clean using a fresh Clarke's solution for weight loss measurements (Jia et al. 2019) and pit depth scanning using a profilometer (Jia et al. 2019). The coupon surfaces were further examined under scanning electron microscopy (Jia et al. 2019).

\section{Electrochemical measurements}

All the electrochemical measurements were executed in $450 \mathrm{~mL}$ glass cells ( $300 \mathrm{~mL}$ EASW plus $3 \mathrm{~mL}$ seed culture). OCP (open circuit potential), LPR (linear polarization resistance), and EIS (electrochemical impedance spectroscopy) were measured daily during the 7 - $d$ incubation period (Jia et al. 2019). Potentiodynamic polarization (PDP) was scanned at the end of the 7 - d incubation (Jia et al. 2019). The counter electrode was a thin platinum sheet $\left(1 \mathrm{~cm}^{2}\right)$ and the reference electrode was a saturated calomel electrode (SCE). A C1018 coupon $\left(1 \mathrm{~cm}^{2}\right)$ in an epoxy cake served as the working electrode. A VersaSTAT 3 potentiostat (Princeton Applied Research, Oak Ridge, TN, USA) was employed.

\section{Results}

\section{Sessile cell enumeration}

Figure 1 shows the sessile cell counts after the 7 - day incubation. The SRB, APB, and GHB cell counts in the biofilm without any biocide treatment were $6.9-\log , 4.5-\log$, and $3.8-\log$, respectively. The 100 ppm glutaraldehyde +200 ppm D-limonene treatment resulted in the lowest sessile cell counts with 2.1, 1.7, and 2.3 - $\log$ reductions for SRB, APB, and GHB, respectively, in comparison with the no treatment control. In comparison, the efficacies using 100 ppm glutaraldehyde alone, and 100 ppm D-limonene alone, were lower. The 100 ppm glutaraldehyde treatment had 1.1, 0.7, and 1.0 - log reductions, whereas 100 ppm D-limonene provided 0.8, 1.0, and 0.8 - log reductions for SRB, APB, and GHB, respectively, in comparison with the no treatment control. The efficacy results for $100 \mathrm{ppm}$ glutaraldehyde + $50 \mathrm{ppm} \mathrm{D-}$ limonene exhibited no significant improvements compared with $100 \mathrm{ppm}$ glutaraldehyde alone treatment. It means that $50 \mathrm{ppm}$ of D-limonene was insufficient to enhance $100 \mathrm{ppm}$ glutaraldehyde.

\section{Corrosion analyses}

Weight loss measurements after the $7-d$ incubation are presented in Fig. 2. The coupons in the abiotic control vial exhibited a small and practically negligible weight loss of $0.2 \pm 0.05 \mathrm{mg} / \mathrm{cm}^{2}$. The maximum weight loss of $3.13 \pm 0.08 \mathrm{mg} / \mathrm{cm}^{2}$ was observed for coupons without treatment (biotic control). The 100 ppm D-limonene treatment gave a slightly smaller weight loss of $2.9 \pm 0.05 \mathrm{mg} / \mathrm{cm}^{2}$ followed by $100 \mathrm{ppm}$ glutaraldehyde treatment, which had $2.7 \pm 0.06 \mathrm{mg} / \mathrm{cm}^{2}$. These data suggested that $100 \mathrm{ppm}$ D-limonene or $100 \mathrm{ppm}$ glutaraldehyde was not very effective in the MIC mitigation. The various combinations of glutaraldehyde + D-limonene led to considerable improvement in weight loss prevention. The combination of $50 \mathrm{ppm}, 100 \mathrm{ppm}$ and $200 \mathrm{ppm}$ D-limonene with $100 \mathrm{ppm}$ glutaraldehyde yielded weight losses of $1.60 \pm 0.08 \mathrm{mg} / \mathrm{cm}^{2}, 1.4 \pm 0.02 \mathrm{mg} / \mathrm{cm}^{2}$ and $1.0 \pm 0.08 \mathrm{mg} / \mathrm{cm}^{2}$, respectively, considerably lower than those for the $100 \mathrm{ppm}$ glutaraldehyde alone treatment and the $100 \mathrm{ppm}$ D-limonene treatment, showing 
synergy for the two anitmicrobials used together. The 100 ppm glutaraldehyde +200 ppm D-limonene treatment yielded the largest weight loss reduction of $68 \%$.

SEM images after the $7-d$ incubation are presented in Fig. 3. It shows a large pit (approximately $30 \mu \mathrm{m}$ in surface diameter) and numerous small pits on the untreated coupon. In comparison with other treatments, $100 \mathrm{ppm}$ glutaraldehyde $+200 \mathrm{ppm}$ D-limonene yielded the least pitting, in agreement with the least weight loss shown in Fig. 2.

Maximum pit depths are reported in Fig. 4. The biotic coupons exhibited a (maximum) pit depth of 24.5 $\mu \mathrm{m}$, largest among all coupons. With $100 \mathrm{ppm}$ of individual biocides, pit depths were found to be $21.7 \mu \mathrm{m}$ and $18.0 \mu \mathrm{m}$ for D-limonene and glutaraldehyde, respectively. For the glutaraldehyde + D-limonene combinations, the pit depths were $13.1 \mu \mathrm{m}, 10.1 \mu \mathrm{m}, 5.4 \mu \mathrm{m}$ for $100 \mathrm{ppm}$ glutaraldehyde in combination with 50 ppm, 100 ppm, and 200 ppm of D-limonene. The 100 ppm glutaraldehyde + 200 ppm D-limonene achieved a pit depth reduction of $78 \%$ compared with the untreated control. The pit depth data here were coherent with the weight loss trend.

\section{Electrochemical tests}

Figure 5 presents OCP during the 7 - $d$ incubation. Theoretically, a more negative OCP suggess that the working electrode is less likely to be reduced or more likely to be oxidized, which also means having a higher thermodynamic tendency to be corroded. The OCP trend in Fig. 5 obviously does not follow the weight loss trend in Fig. 2, because the data do not show the 100 ppm glutaraldehyde +200 ppm Dlimonene OCP curve on top and the no-treatment OCP curve at the bottom. This discrepancy is common for MIC of carbon steel. Because for a complicated MIC system, an electron acceptor (oxidant) in the culture medium can exhibit a large thermodynamic tendency to grab electrons from the C1018 working electrode, but the process can be kinetically hindered due to a high activation energy for the reduction of the oxidant. Kinetic electrochemical tests have repeatedly proven that kinetic electrochemical data are in agreement with weight loss and pit depth data trends, despite misleading OCP trends (Jia et al. 2019).

Figure 6 exhibits the transient trend of polarization resistance $\left(R_{\mathrm{p}}\right)$ during the 7 - $\mathrm{d}$ incubation. The untreated coupon had the lowest $R_{\mathrm{p}}$ value, meaning the highest corrosion rate, compared to all biocide treated coupons throughout the test duration. The $100 \mathrm{ppm}$ glutaraldehyde $+200 \mathrm{ppm}$ D-limonene treatment had the highest $R_{\mathrm{p}}$ over the incubation period; however, there was a sharp drop on the 4th day. This $R_{\mathrm{p}}$ fall shared the same pattern with $100 \mathrm{ppm}$ glutaraldehyde $+100 \mathrm{ppm}$ D-limonene treatment. This could mean that initially, D-limonene treatment was effective, but the effect waned over time. The $R_{\mathrm{p}}$ data here provided useful transient corrosion behavior corresponding to biocide treatment. This transient information is not available from the cumulative weight loss or pit depth data. It means that this simple electrochemical method is a useful tool in biocide efficacy assessment.

EIS was scanned daily. Nyquist and Bode plots on the day 7th are shown in Fig. 7 and Fig. 8, respectively. The 100 ppm glutaraldehyde +200 ppm D-limonene treatment provided the largest semi-circle diameter, 
which means the highest corrosion resistance. The EIS fitted parameters are given in Table 3 using the equivalent circuit model illustrated in Fig. 9, in which $R_{\mathrm{S}}, R_{\mathrm{f}}$, and $R_{\mathrm{ct}}$ represent solution resistance, film resistance (biofilm and corrosion products), and charge transfer resistance, respectively. The $R_{\mathrm{f}}+R_{\mathrm{ct}}$ combination can be used to describe corrosion resistance (Jia et al. 2019). In Table 3, $R_{\mathrm{f}}+R_{\mathrm{ct}}$ values indicate that the $100 \mathrm{ppm}$ glutaraldehyde $+200 \mathrm{ppm}$ D-limonene treatment out-performed other treatments. It provides an approximately $200 \%$ increase in corrosion resistance compared to the untreated coupon, much greater than using $100 \mathrm{ppm}$ glutaraldehyde alone or $100 \mathrm{D}$-limonene alone. The $R_{\mathrm{f}}+R_{\mathrm{ct}}$ (scanned using alternate current in EIS) trend corroborated $R_{\mathrm{p}}$ (scanned with direct current in LPR) and weight loss trends.

Table 3

EIS-derived electrochemical parameters after 7 - d incubation.

\begin{tabular}{|c|c|c|c|c|c|c|c|}
\hline Treatment & $\begin{array}{l}R_{\mathrm{s}} \\
(\Omega \\
\left.\mathrm{cm}^{2}\right)\end{array}$ & $\begin{array}{l}Y_{\mathrm{f}} \\
\left(\Omega^{-1} \mathrm{~cm}^{-}\right. \\
\left.{ }^{2} \mathrm{~s}^{\mathrm{n}}\right)\end{array}$ & $n_{\mathrm{f}}$ & $\begin{array}{l}R_{\mathrm{f}} \\
\left(\mathrm{k} \Omega \mathrm{cm}^{2}\right)\end{array}$ & $\begin{array}{l}Y_{\mathrm{dl}} \\
\left(\Omega^{-1}\right. \\
\mathrm{cm}^{-2} \\
\left.\mathrm{~s}^{\mathrm{n}}\right)\end{array}$ & $n_{\mathrm{dl}}$ & $\begin{array}{l}R_{\mathrm{ct}} \\
(\mathrm{k} \Omega \\
\left.\mathrm{cm}^{2}\right)\end{array}$ \\
\hline No treatment & 6.72 & $5.3 \times 10^{-3}$ & 1 & $l^{1.03 \times 10^{-}}$ & 0.426 & 0.43 & 1.84 \\
\hline 100 ppm D-limonene & 4.39 & $2.7 \times 10^{-3}$ & 1 & $\begin{array}{l}5.95 \times 10^{-} \\
3\end{array}$ & 0.912 & 0.91 & 1.94 \\
\hline 100 ppm glutaraldehyde & 6.43 & $3.5 \times 10^{-3}$ & 1 & $\begin{array}{l}7.31 \times 10^{-} \\
2\end{array}$ & 0.504 & 0.50 & 2.04 \\
\hline $\begin{array}{l}100 \text { ppm glutaraldehyde }+50 \\
\text { ppm D-limonene }\end{array}$ & 5.18 & $8.2 \times 10^{-3}$ & 1 & $\begin{array}{l}4.14 \times 10^{-} \\
3\end{array}$ & 0.763 & 0.76 & 3.30 \\
\hline $\begin{array}{l}100 \text { ppm glutaraldehyde }+100 \\
\text { ppm D-limonene }\end{array}$ & 6.67 & $1.3 \times 10^{-2}$ & 1 & $2.59 \times 10^{-}$ & 0.451 & 0.45 & 3.02 \\
\hline $\begin{array}{l}100 \text { ppm glutaraldehyde }+200 \\
\text { ppm D-limonene }\end{array}$ & 3.23 & $8.3 \times 10^{-3}$ & 1 & $2^{1.19 \times 10^{-}}$ & 0.753 & 0.75 & 5.67 \\
\hline
\end{tabular}

PDP curves at the end of the $7-d$ incubation are shown in Fig. 10. The fitted Tafel are listed in Table 4. The $i_{\text {corr }}$ value was $38.4 \mu \mathrm{A} / \mathrm{cm}^{2}$ for the untreated coupon. For individual biocide treatments, the $i_{\text {corr }}$ value for $100 \mathrm{ppm} D$-limonene alone was $19.7 \mu \mathrm{A} / \mathrm{cm}^{2}$, and it was $14.1 \mu \mathrm{A} / \mathrm{cm}^{2}$ for $100 \mathrm{ppm}$ glutaraldehyde alone. For the combination treatments, the $i_{\text {corr }}$ values were $13.7 \mu \mathrm{A} / \mathrm{cm}^{2}$ for $100 \mathrm{ppm}$ glutaraldehyde +50 ppm D-limonene, $12.3 \mu \mathrm{A} / \mathrm{cm}^{2}$ for $100 \mathrm{ppm}$ glutaraldehyde $+100 \mathrm{ppm}$ D-limonene, and $7.9 \mu \mathrm{A} / \mathrm{cm}^{2}$ for 
100 ppm glutaraldehyde +200 ppm D-limonene. The 100 ppm glutaraldehyde +200 ppm D-limonene treatment achieved the best outcome, confirming the weight loss data.

Table 4

Parameters from potentiodynamic curves after 7 - $d$ of incubation.

\begin{tabular}{|lllll|}
\hline Treatment & $\begin{array}{l}i_{\text {corr }}(\mu \mathrm{A} \\
\left.\mathrm{cm}^{-2}\right)\end{array}$ & $\begin{array}{l}E_{\text {corr }}(\mathrm{mV}) \text { vs. } \\
\text { SCE }\end{array}$ & $\begin{array}{l}\beta_{\mathrm{a}}(\mathrm{mV} \\
\left.\mathrm{dec}^{-1}\right)\end{array}$ & $\begin{array}{l}\boldsymbol{\beta}_{\mathrm{c}}(\mathrm{mV} \\
\left.\mathrm{dec}^{-1}\right)\end{array}$ \\
\hline No treatment & 38.4 & -740 & 494 & 86 \\
\hline 100 ppm D-limonene & 19.7 & -684 & 76 & 31 \\
\hline 100 ppm glutaraldehyde & 14.1 & -614 & 43 & 89 \\
\hline $\begin{array}{l}100 \text { ppm glutaraldehyde + } 50 \text { ppm D- } \\
\text { limonene }\end{array}$ & 13.7 & -733 & 13 & 88 \\
\hline $\begin{array}{l}100 \text { ppm glutaraldehyde + } 100 \text { ppm D- } \\
\text { limonene }\end{array}$ & 12.3 & -790 & 288 & 169 \\
\hline $\begin{array}{l}100 \text { ppm glutaraldehyde + } 200 \text { ppm D- } \\
\text { limonene }\end{array}$ & 7.9 & -758 & 355 & 106 \\
\hline
\end{tabular}

\section{Discussion}

Consortium II caused MIC of C1018 carbon steel in deoxygenated EASW. After 7-d incubation, the sessile cell counts of the untreated coupons for SRB, APB and GHB were $6.9-\log , 4.5-\log$, and $3.8-\log$, respectively. They were reduced to $4.8-\log , 2.8-\log$, and $1.5-\log$, respectively with the $100 \mathrm{ppm}$ glutaraldehyde +200 ppm D-limonene combination treatment in the biofilm prevention test. The combination treatment was much more superior to the individual $100 \mathrm{ppm}$ glutaraldehyde alone, 100 ppm D-limonene alone treatments and 100 ppm glutaraldehyde +100 ppm D-limonene treatment. The $100 \mathrm{ppm}$ glutaraldehyde $+200 \mathrm{ppm}$ D-limonene treatment reduced sessile cell counts of SRB, APB and GHB by $2.1,1.7$, and $2.3-\log$, respectively, compared to the untreated biotic control. The antimicrobial activity of D-limonene has been discussed in the literature (Van vuuren and Viljoen 2007; Settanni et al. 2012); therefore, the reduction of sessile cell by cocktail treatment demonstrated the synergy between Dlimonene and glutaraldehyde to achieve higher antimicrobial efficacy. The weight loss and pit depth were also considerably reduced, which were corroborated by LPR, EIS and PDP data. The $100 \mathrm{ppm}$ glutaraldehyde +200 ppm D-limonene treatment led to a $68 \%$ reduction in weight loss, and $78 \%$ reduction in pit depth after the 7-d incubation. The $i_{\text {corr }}$ data after the $7-d$ incubation indicated a $79 \%$ reduction achieved by the 100 ppm glutaraldehyde +200 ppm D-limonene treatment, not far from the $68 \%$ reduction in weight loss. Thus, D-limonene enhanced glutaraldehyde in MIC mitigation alternatively to D-amino acid based enhancer (Wen et al. 2009; Xu et al. 2012). 


\section{Conclusion}

The experiment results indicated $200 \mathrm{ppm}$ D-limonene enhanced $100 \mathrm{ppm}$ glutaraldehyde in the biofilm prevention against Consortium II oilfield MIC of carbon steel. The treatment with $200 \mathrm{ppm}$ D-limonene + $100 \mathrm{ppm}$ glutaraldehyde exhibited the 2.1 - $\log , 1.7$ - $\log$, and $2.3-\log$ reduction for SRB, APB, and GHB, respectively, in comparison with the untreated control. The treatment achieved higher efficacy in biofilm prevention and MIC mitigation than using glutaraldehyde and D-limonene individually. The electrochemical tests corroborated weight loss and pit depth data trends.

\section{Declarations}

\section{Acknowledgments}

This work was supported by Saudi Aramco, Saudi Arabia, and PTT Exploration and Production, Thailand.

\section{References}

Bade K, Manz W, Szewzyk U (2000) Behavior of sulfate reducing bacteria under oligotrophic conditions and oxygen stress in particle-free systems related to drinking water. FEMS Microbiol Ecol 32:215-223 . https://doi.org/10.1111/j.1574-6941.2000.tb00714.x

Chikhoune A, Hazzit M, Kerbouche L, Baaliouamer A, Aissat K (2013) Tetraclinis articulata (Vahl) Masters essential oils: chemical composition and biological activities. J Essent Oil Res 25:300-307 . https://doi.org/10.1080/10412905.2013.774625

Dabbah R, Edwards VM, Moats WA (1970) Antimicrobial action of some citrus fruit oils on selected foodborne bacteria. Appl Microbiol 19:27-31

Dall'Agnol L, Moura J (2014) Sulphate reducing bacteria (SRB) and biocorrosion. In: Understanding Biocorrosion: Fundamentals and Applications. pp 121-151

Gu T, Jia R, Unsal T, Xu D (2018) Toward a better understanding of microbiologically influenced corrosion cause by sulfate reducing bacteria. J Mater Sci Technol 35: . https://doi.org/10.1016/j.jmst.2018.10.026

Javaherdashti R (1999) A review of some characteristics of MIC caused by sulfate-reducing bacteria: past, present and future. Anti-Corros Methods Mater 46:173-180 .

https://doi.org/10.1108/00035599910273142

Jia R, Li Y, Al-Mahamedh HH, Gu T (2017) Enhanced Biocide Treatments with D-amino Acid Mixtures against a Biofilm Consortium from a Water Cooling Tower. Front Microbiol 8:1538-1538 .

https://doi.org/10.3389/fmicb.2017.01538 
Jia R, Wang D, Jin P, Unsal T, Yang D, Yang J, Xu D, Gu T (2019) Effects of ferrous ion concentration on microbiologically influenced corrosion of carbon steel by sulfate reducing bacterium Desulfovibrio vulgaris. Corros Sci 153:127-137 . https://doi.org/10.1016/j.corsci.2019.03.038

Keasler V, De Paula RM, Nilsen G, Grunwald L, Tidwell TJ (2017) 23 - Biocides overview and applications in petroleum microbiology. In: El-Sherik AM (ed) Trends in Oil and Gas Corrosion Research and Technologies. Woodhead Publishing, Boston, pp 539-562

Kim YW, Kim MJ, Chung BY, Bang DY, Lim SK, Choi SM, Lim DS, Cho MC, Yoon K, Kim HS, Kim KB, Kim YS, Kwack SJ, Lee B-M (2013) Safety evaluation and risk assessment of d-Limonene. J Toxicol Environ Health B Crit Rev 16:17-38 . https://doi.org/10.1080/10937404.2013.769418

Migneault I, Dartiguenave C, Bertrand M, Waldron K (2004) Glutaraldehyde: behavior in aqueous solution, reaction with proteins, and application to enzyme crosslinking. BioTechniques 37:790-802 . https://doi.org/10.2144/04375RV01

Rasol R, Noor N, Mat Din M (2014) Effect of Temperature in SRB Growth for Oil and Gas Pipeline Settanni L, Palazzolo E, Guarrasi V, Aleo A, Mammina C, Moschetti G, Germanà MA (2012) Inhibition of foodborne pathogen bacteria by essential oils extracted from citrus fruits cultivated in Sicily. Food Control 26:326-330 . https://doi.org/10.1016/j.foodcont.2012.01.050

Van vuuren S, Viljoen A (2007) Antimicrobial activity of limonene enantiomers and 1,8-cineole alone and in combination. Flavour Fragr J 22:540-544 . https://doi.org/10.1002/ffj.1843

Wen J, Zhao K, Gu T, Raad II (2009) A green biocide enhancer for the treatment of sulfate-reducing bacteria (SRB) biofilms on carbon steel surfaces using glutaraldehyde. Int Biodeterior Biodegrad 63:1102-1106 . https://doi.org/10.1016/j.ibiod.2009.09.007

Xu D, Wen J, Fu W, Gu T, Raad I (2012) D-amino acids for the enhancement of a binary biocide cocktail consisting of THPS and EDDS against an SRB biofilm. World J Microbiol Biotechnol 28:1641-1646 . https://doi.org/10.1007/s11274-011-0970-5

\section{Tables}

Table 1. Composition of C1018 carbon steel.

\begin{tabular}{llllllllll}
\hline Element & $\mathrm{C}$ & $\mathrm{Mn}$ & $\mathrm{P}$ & $\mathrm{Cr}$ & $\mathrm{S}$ & $\mathrm{Mo}$ & $\mathrm{Si}$ & $\mathrm{Ni}$ & $\mathrm{Fe}$ \\
\hline Amount (wt\%) & 0.200 & 0.900 & 0.017 & 0.061 & 0.012 & 0.018 & 0.044 & 0.044 & balance \\
\hline
\end{tabular}

Table 2. Composition of enriched artificial seawater. 


\begin{tabular}{lc}
\hline Chemical & Amount (g) \\
\hline $\mathrm{Na}_{2} \mathrm{SO}_{4}$ & 0.200 \\
$\mathrm{NaCl}$ & 23.476 \\
$\mathrm{NaHCO}$ & 0.192 \\
$\mathrm{KBr}$ & 0.096 \\
$\mathrm{KCl}$ & 0.664 \\
$\mathrm{H}_{3} \mathrm{BO}_{3}$ & 0.026 \\
$\mathrm{SrCl}_{2} \times 6 \mathrm{H}_{2} \mathrm{O}$ & 0.040 \\
$\mathrm{MgCl}_{2} \times 6 \mathrm{H}_{2} \mathrm{O}$ & 10.610 \\
$\mathrm{CaCl}_{2} \times 2 \mathrm{H}_{2} \mathrm{O}$ & 1.469 \\
$\mathrm{Yeast} \mathrm{extract}$ & 1 \\
$\mathrm{Tri}_{-} \mathrm{Sodium} \mathrm{citrate}$ & 0.5 \\
$\mathrm{Sodium} \mathrm{lactate}_{\mathrm{CaSO}} \times 0.5 \mathrm{H}_{2} \mathrm{O}$ & 3.5 \\
$\mathrm{CaSh}_{4}$ & 0.1 \\
$\mathrm{NH}_{4} \mathrm{Cl}$ & 0.1 \\
$\mathrm{MgSO}_{4} \times 7 \mathrm{H}_{2} \mathrm{O}$ & 0.71 \\
$\mathrm{Fe}\left(\mathrm{NH}_{4}\right)_{2}\left(\mathrm{SO}_{4}\right)_{2} \times 6 \mathrm{H}_{2} \mathrm{O}$ & 1.38 \\
Di water & $1 \mathrm{~L}$ \\
\hline
\end{tabular}

Table 3. EIS-derived electrochemical parameters after 7-d incubation.

\begin{tabular}{|c|c|c|c|c|c|c|c|}
\hline reatment & $\begin{array}{c}R_{\mathrm{S}} \\
(\Omega \\
\left.\mathrm{cm}^{2}\right)\end{array}$ & $\begin{array}{c}Y_{\mathrm{f}} \\
\left(\Omega^{-1} \mathrm{~cm}^{-2}\right. \\
\left.\mathrm{s}^{\mathrm{n}}\right)\end{array}$ & $n_{\mathrm{f}}$ & $\begin{array}{c}R_{\mathrm{f}} \\
\left(\mathrm{k} \Omega \mathrm{cm}^{2}\right)\end{array}$ & $\begin{array}{c}Y_{\mathrm{dl}} \\
\left(\Omega^{-1}\right. \\
\mathrm{cm}^{-2} \\
\left.\mathrm{~s}^{\mathrm{n}}\right)\end{array}$ & $n_{\mathrm{dl}}$ & $\begin{array}{r}R_{\mathrm{Ct}} \\
(\mathrm{k} \Omega \\
\left.\mathrm{cm}^{2}\right)\end{array}$ \\
\hline 「o treatment & 6.72 & $5.3 \times 10^{-3}$ & 1 & $1.03 \times 10^{-2}$ & 0.426 & 0.43 & 1.84 \\
\hline 00 ppm D-limonene & 4.39 & $2.7 \times 10^{-3}$ & 1 & $5.95 \times 10^{-3}$ & 0.912 & 0.91 & 1.94 \\
\hline 00 ppm glutaraldehyde & 6.43 & $3.5 \times 10^{-3}$ & 1 & $7.31 \times 10^{-2}$ & 0.504 & 0.50 & 2.04 \\
\hline $\begin{array}{l}00 \text { ppm glutaraldehyde }+50 \\
\text { pm D-limonene }\end{array}$ & 5.18 & $8.2 \times 10^{-3}$ & 1 & $4.14 \times 10^{-3}$ & 0.763 & 0.76 & 3.30 \\
\hline $\begin{array}{l}00 \text { ppm glutaraldehyde }+100 \\
\text { pm D-limonene }\end{array}$ & 6.67 & $1.3 \times 10^{-2}$ & 1 & $2.59 \times 10^{-1}$ & 0.451 & 0.45 & 3.02 \\
\hline $\begin{array}{l}00 \text { ppm glutaraldehyde }+200 \\
\text { pm D-limonene }\end{array}$ & 3.23 & $8.3 \times 10^{-3}$ & 1 & $1.19 \times 10^{-2}$ & 0.753 & 0.75 & 5.67 \\
\hline
\end{tabular}

Table 4. Parameters from potentiodynamic curves after 7-d of incubation. 


\begin{tabular}{|c|c|c|c|c|}
\hline eatment & $\begin{array}{c}i_{\mathrm{corr}}(\mu \mathrm{A} \\
\left.\mathrm{cm}^{-2}\right)\end{array}$ & $\begin{array}{c}E_{\text {Corr }}(\mathrm{mV}) \text { vs. } \\
\text { SCE }\end{array}$ & $\begin{array}{l}\beta_{\mathrm{a}}(\mathrm{mV} \\
\left.\mathrm{dec}^{-1}\right)\end{array}$ & $\begin{array}{l}\beta_{\mathrm{c}}(\mathrm{mV} \\
\left.\operatorname{dec}^{-1}\right)\end{array}$ \\
\hline o treatment & 38.4 & -740 & 494 & 86 \\
\hline 10 ppm D-limonene & 19.7 & -684 & 76 & 31 \\
\hline 10 ppm glutaraldehyde & 14.1 & -614 & 43 & 89 \\
\hline $\begin{array}{l}10 \text { ppm glutaraldehyde }+50 \text { ppm } \\
\text { limonene }\end{array}$ & 13.7 & -733 & 13 & 88 \\
\hline $\begin{array}{l}10 \mathrm{ppm} \text { glutaraldehyde }+100 \text { ppm } \\
\text { limonene }\end{array}$ & 12.3 & -790 & 288 & 169 \\
\hline $\begin{array}{l}10 \text { ppm glutaraldehyde }+200 \text { ppm } \\
\text { limonene }\end{array}$ & 7.9 & -758 & 355 & 106 \\
\hline
\end{tabular}

\section{Figures}

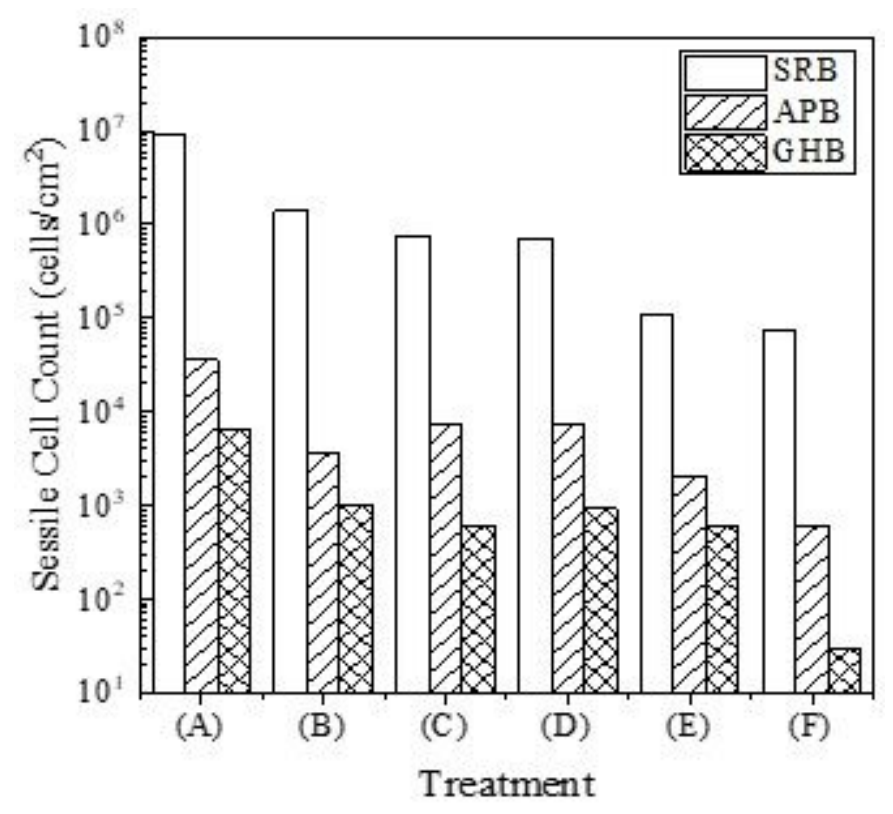

\section{Figure 1}

Sessile cell counts: (A) No treatment, (B) 100 ppm D-limonene, (C) 100 ppm glutaraldehyde, (D) 100 ppm glutaraldehyde +50 ppm D-limonene, (E) 100 ppm glutaraldehyde +100 ppm D-limonene, (F) 100 ppm glutaraldehyde +200 ppm D-limonene. 


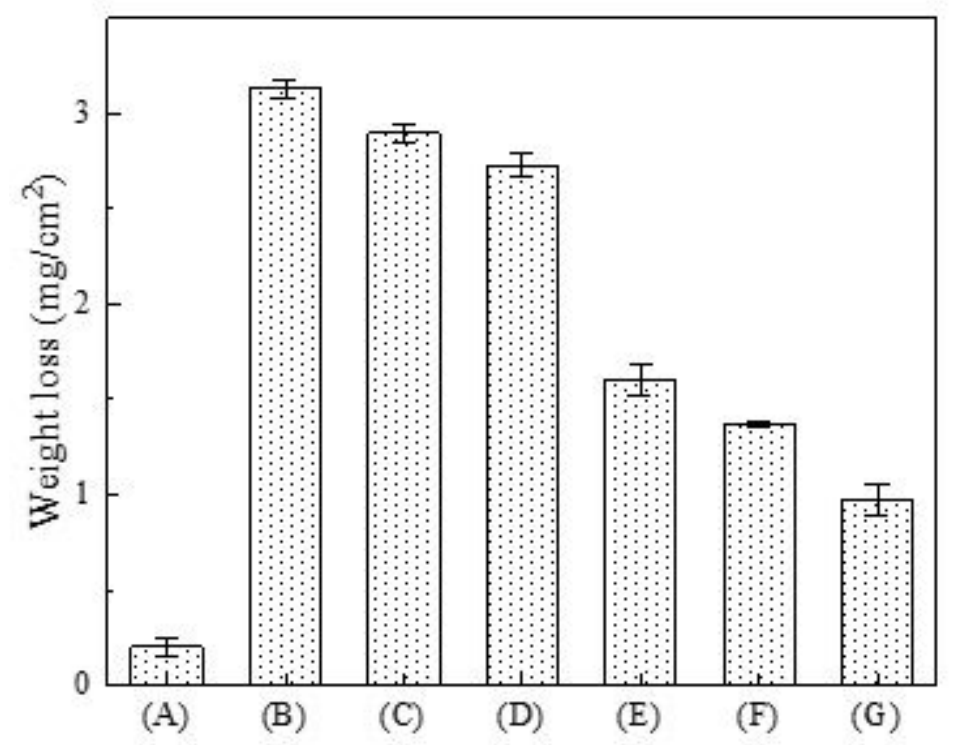

Figure 2

Weight losses after 7-day incubation: (A) Abiotic, (B) no treatment, (C) 100 ppm D-limonene, (D) 100 ppm glutaraldehyde, $(\mathrm{E}) 100 \mathrm{ppm}$ glutaraldehyde $+50 \mathrm{ppm}$ D-limonene, $(\mathrm{F}) 100 \mathrm{ppm}$ glutaraldehyde +100 ppm D-limonene, (G) 100 ppm glutaraldehyde + 200 ppm D-limonene. 

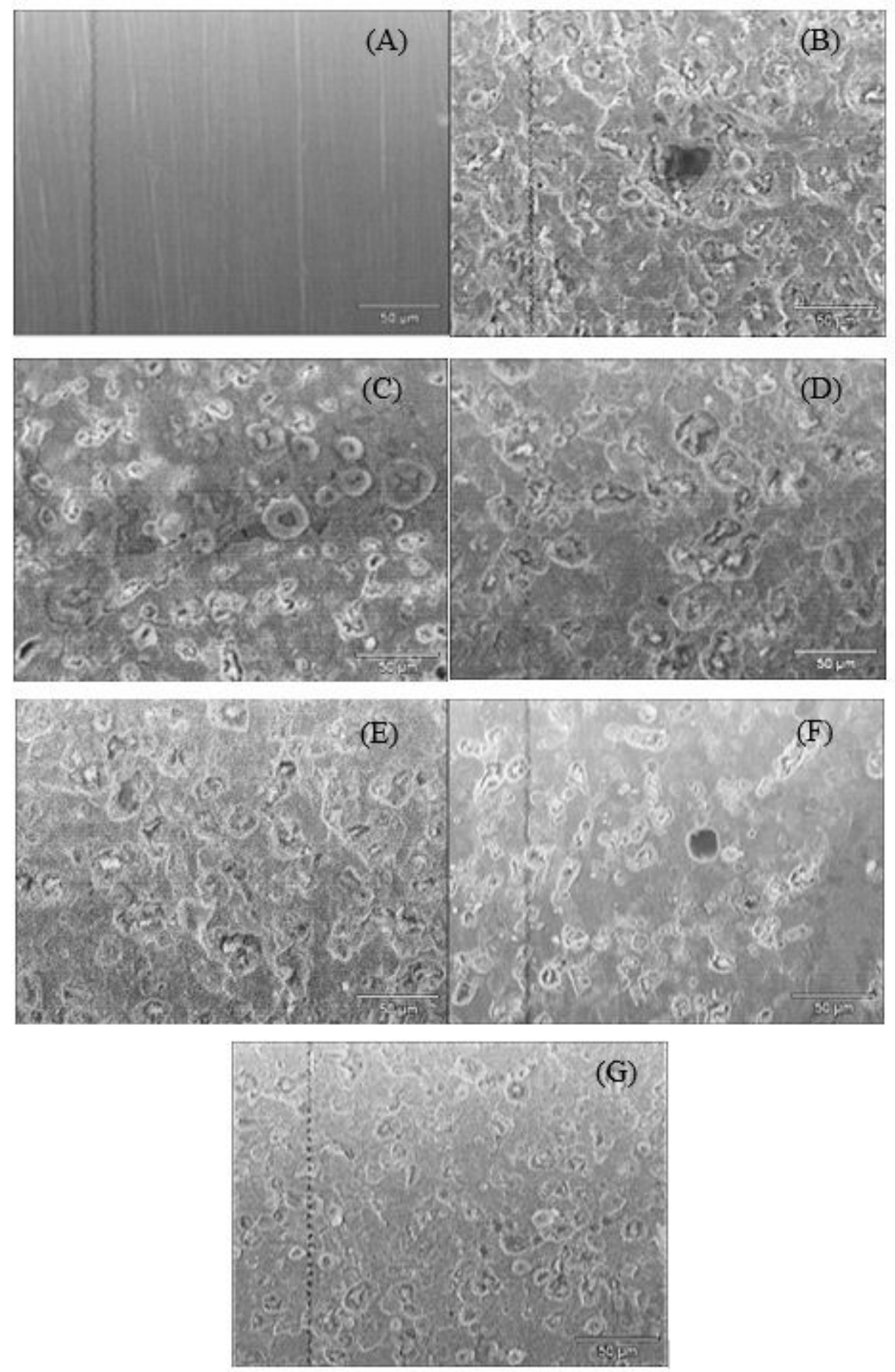

\section{Figure 3}

SEM images of coupons after 7-d of incubation: (A) Abiotic, (B) no treatment, (C) 100 ppm D-limonene, (D) 100 ppm glutaraldehyde, (E) 100 ppm glutaraldehyde + 50 ppm D-limonene, (F) 100 ppm glutaraldehyde + 100 ppm D-limonene, (G) 100 ppm glutaraldehyde + 200 ppm D-limonene. 


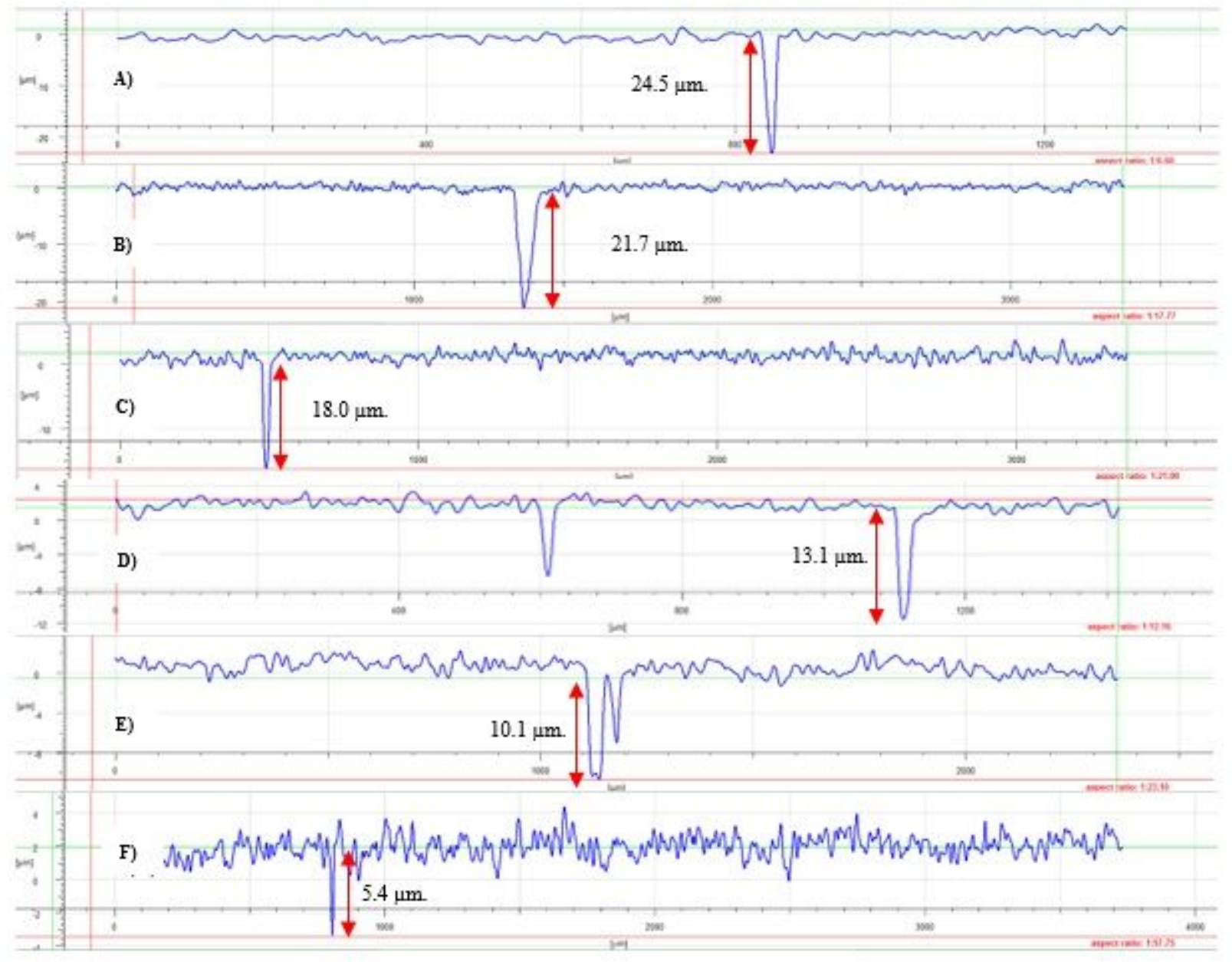

\section{Figure 4}

Pit depths for: (A) No treatment, (B) 100 ppm D-limonene, (C) 100 ppm glutaraldehyde, (D) 100 ppm glutaraldehyde +50 ppm D-limonene, (E) 100 ppm glutaraldehyde +100 ppm D-limonene, (F) 100 ppm glutaraldehyde + 200 ppm D-limonene. 


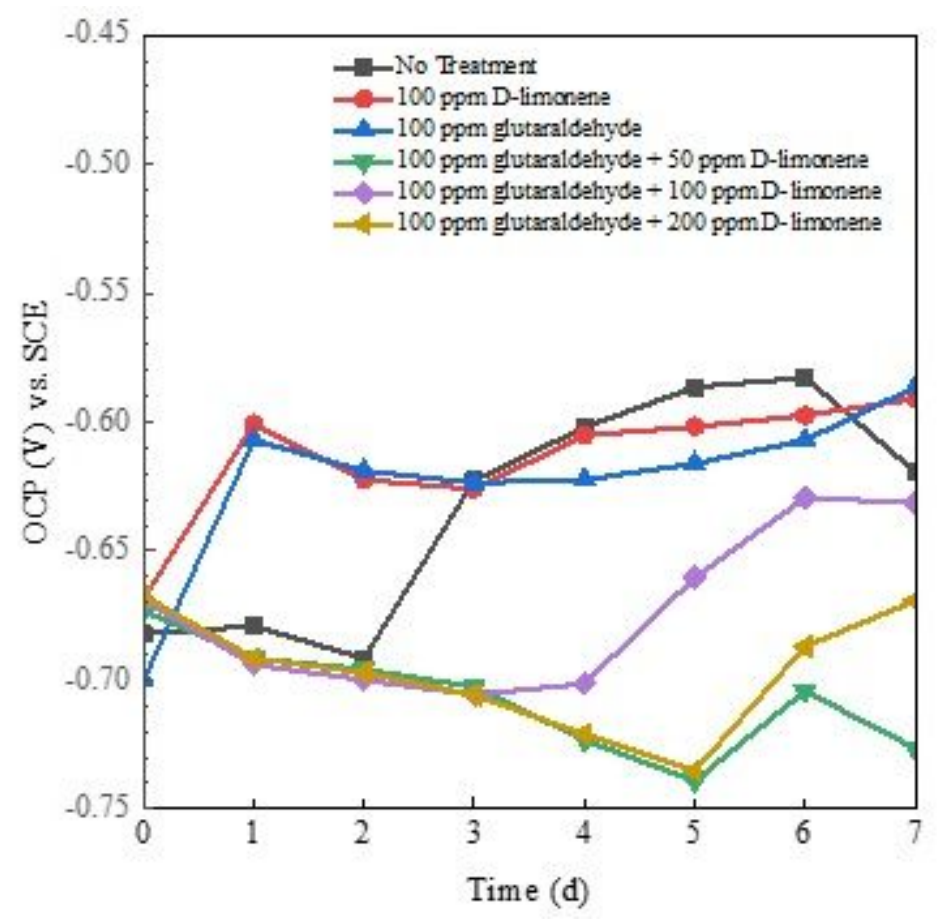

Figure 5

Variations of OCP during the 7-d incubation.

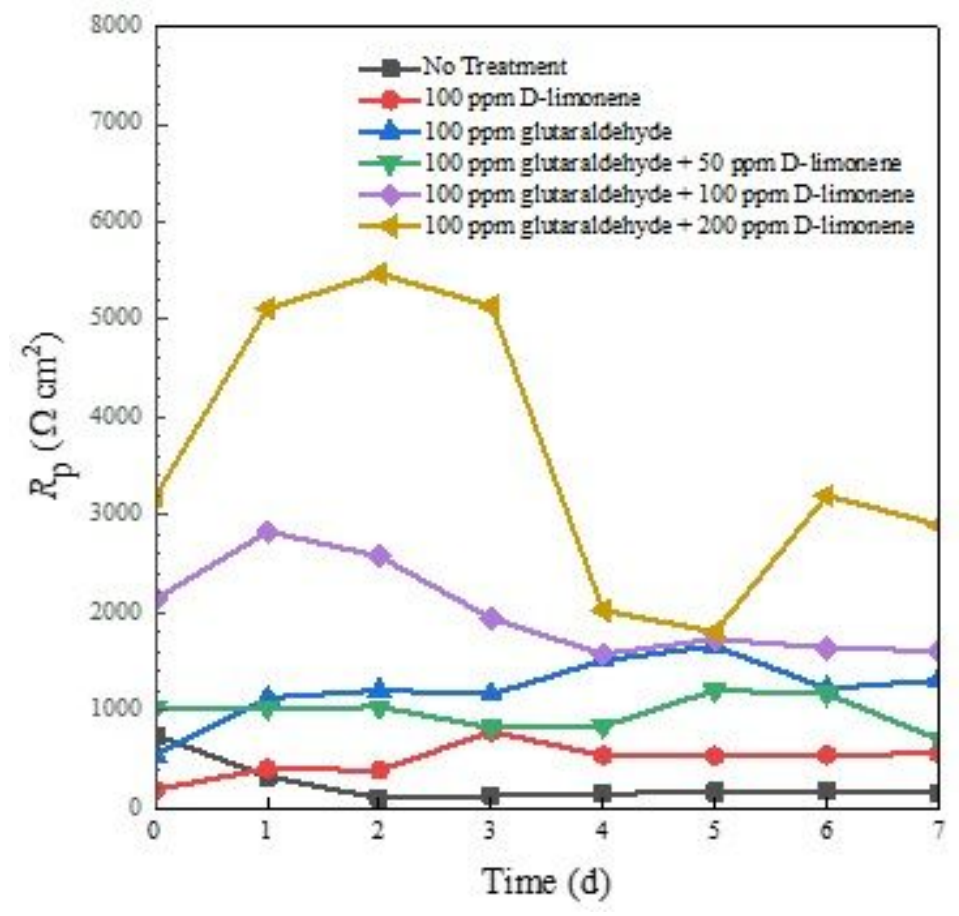

\section{Figure 6}

Rp values vs. time during the 7-d incubation. 


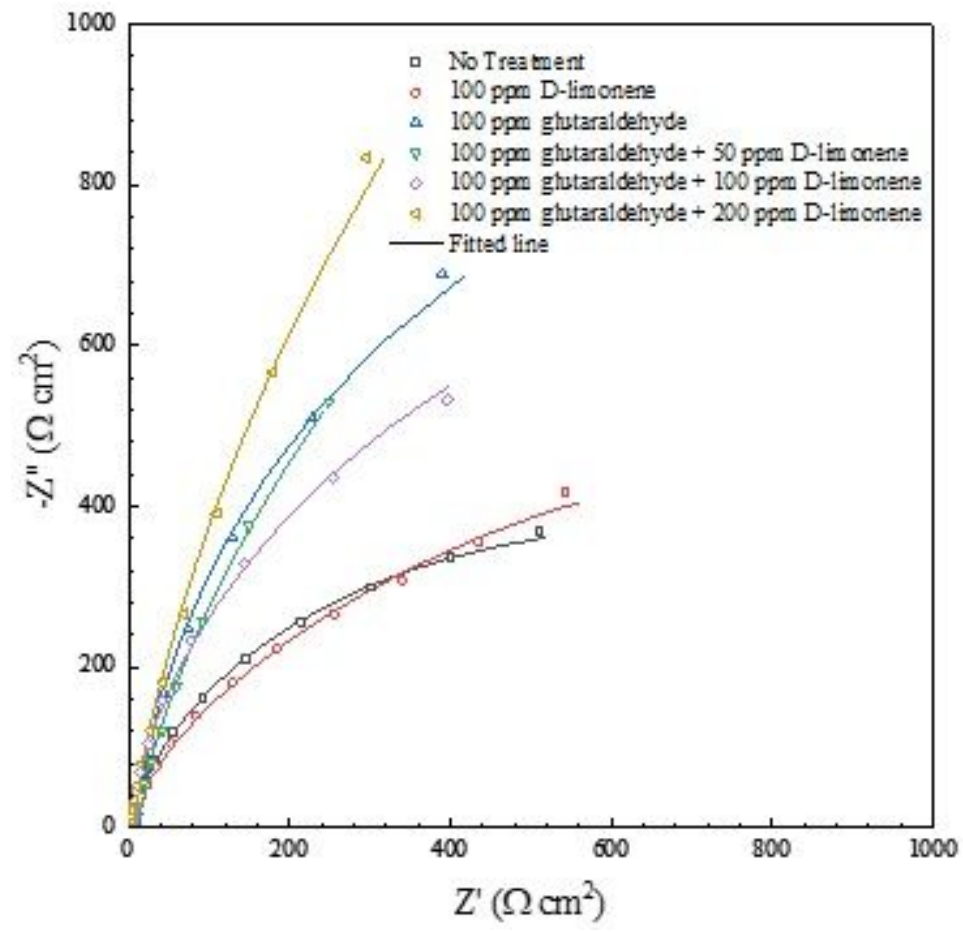

Figure 7

Nyquist plots after 7-d incubation.

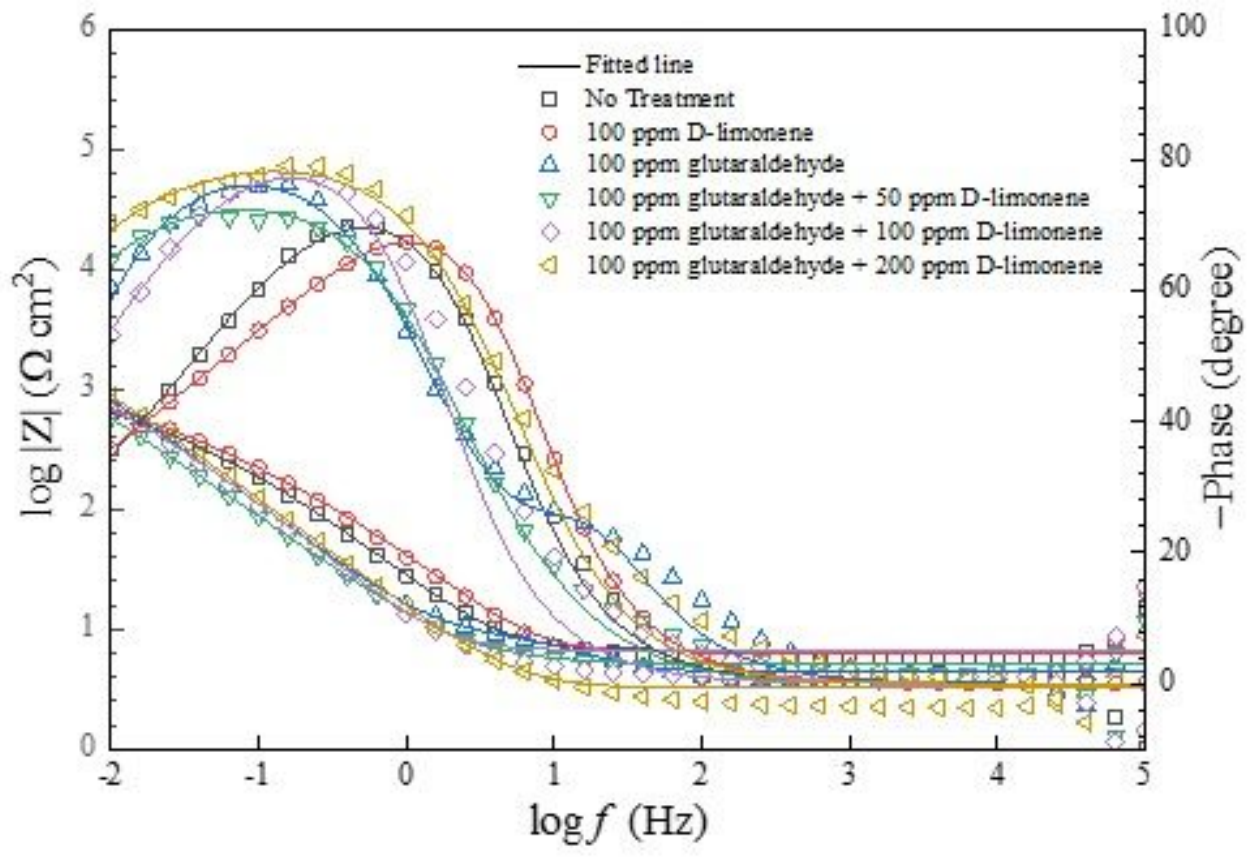

\section{Figure 8}

Bode and phase-frequency plots after 7-d incubation. 
W

Figure 9

Equivalent circuits used for fitting EIS spectra.

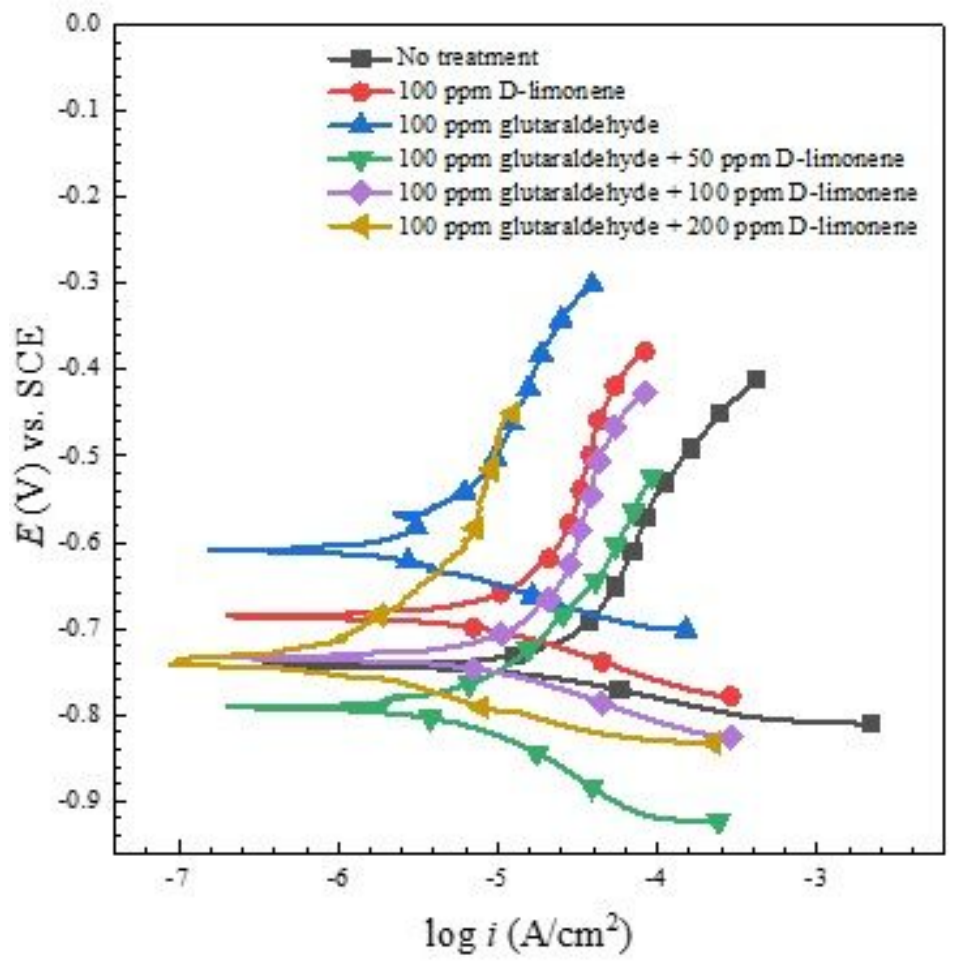

Figure 10

PDP curves after 7-d of incubation. 